\title{
Trapping methods for capturing the screwworm Telchin atymnius (Dalman, 1824) on plantain plantations (Musa AAB)
}

\section{Métodos de trampeo para la captura del gusano tornillo Telchin atymnius (Dalman, 1824) en cultivos de plátano (Musa AAB)}
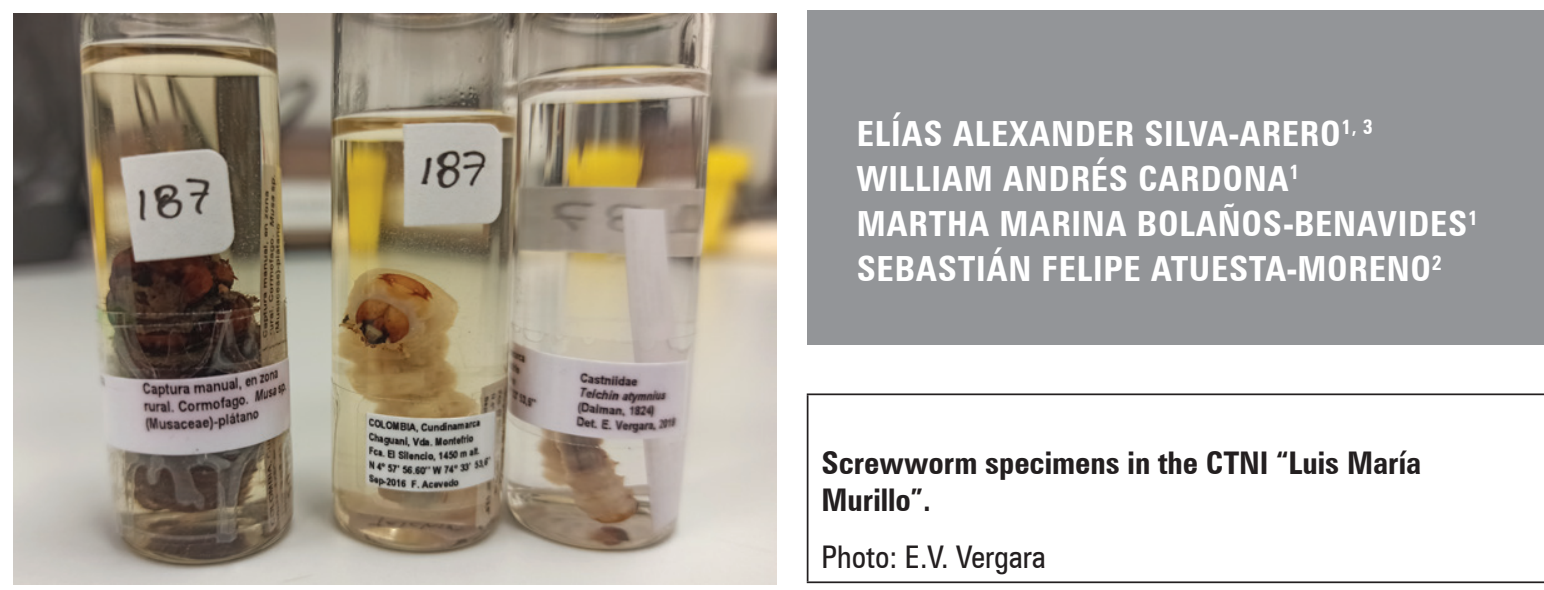

Screwworm specimens in the CTNI “Luis María Murillo".

Photo: E.V. Vergara

\begin{abstract}
The larval stage of the screwworm (Telchin atymnius) inflicts damage on the pseudostem and corm, allowing other pests and pathogens to affect crops and decrease fruit yield and quality. The adults form of these insects are attracted to certain colors and types of food, and their capture reduces oviposition and damage from future larvae. The objective of this study was to evaluate the efficacy of capturing adult individuals on plantain farms through two experiments: a) using traps with different colors (blue, white, and transparent) and b) using two types of traps (the most efficient color trap of the prior experiment and an artisanal trap). A completely randomized experiment design was used. The insects were recorded through counting. Binomial negative, Poisson and zero-inflated variation models were used for data analysis. Furthermore, temperature and rainfall variables were included as statistical model parameters of the color trap experiment. The parameters were considered significant when $P<0.05$. SAS 9.4 was used. The number of individuals captured with the blue and white traps were 2.84 and 1.38 times higher than the numbers captured with the transparent trap, respectively. In addition, there were 6.26 times more captures in months with higher temperatures than in months with lower temperatures. With the artisanal trap, there were 4.33 times more captures than in

1 Corporación Colombiana de Investigación Agropecuaria - Agrosavia, Mosquera (Colombia). ORCID Silva-Arero, E.A.: 0000-0001-7075-1318; ORCID Cardona, W.A.: 0000-0001-9610-4135; ORCID Bolaños-Benavides, M.M.: 0000-0003-4593-5523

2 Eko Bojacá, Bogota (Colombia). ORCID Atuesta-Moreno, S.F.: 0000-0003-4517-8745

Corresponding author. esilva@agrosavia.co
\end{abstract}


blue traps; it was also the cheapest trap. The use of blue traps (bags) with toxic bait or traps with molasses bait is a viable alternative for monitoring and capturing this insect with integrated management.

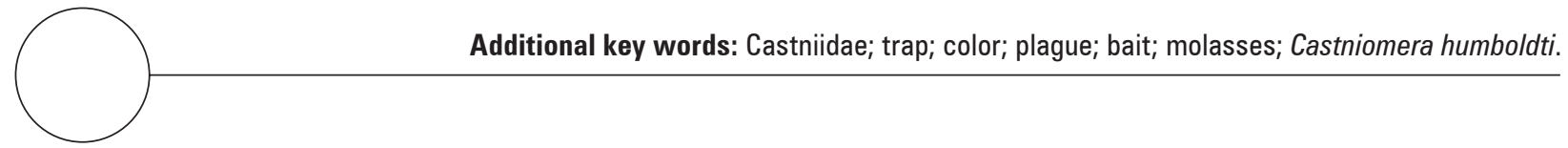

\section{RESUMEN}

El estado larval del gusano tornillo (Telchin atymnius) genera daños en pseudotallo y cormo del plátano, facilita entrada de plagas y patógenos y disminuye rendimiento y calidad del fruto. Estos insectos son atraídos por ciertos colores o tipo de alimento. El objetivo de esta investigación fue evaluar la captura de adultos del gusano tornillo: a) con la eficacia de diferentes colores (azul, blanco y trasparente), y b) dos tipos de trampa (la trampa de color más eficiente del experimento previo y una trampa artesanal). En ambos experimentos se utilizó un diseño experimental completamente aleatorizado; dado que los individuos se registraron mediante conteos, se implementaron modelos: binomial negativo, Poisson y sus variaciones inflados de ceros para el análisis. Adicionalmente, se incluyeron las variables temperatura y precipitación como parámetros del modelo estadístico del experimento de colores de trampa. Los parámetros se consideraron significativos cuando presentaron $P<0,05$. Para el análisis estadístico, se utilizó el programa SAS 9.4. La trampa azul y blanca tuvieron 2,84 y 1,38 veces más capturas que la trampa trasparente; y con el incremento en la temperatura se obtuvo 6,26 veces más capturas que en el mes con más baja temperatura. Con la trampa artesanal, se tuvo 4,33 veces más capturas que con la trampa azul; además, es la más económica. El uso de trampas (bolsas) azules con cebo tóxico o trampas artesanales con melaza como cebo, son una alternativa viable de monitoreo y captura dentro de un manejo integrado del insecto.

Palabras clave adicionales: Castniidae; trampa; color; plaga; cebo; melaza; Castniomera humboldti.

Received for publication: 22-07-2019 Accepted for publication: 11-06-2020

INTRODUCTION

In 2018 in Colombia, the estimated planted area with plantain crops in the country was equivalent to 440,294 ha, with 4.3 million tons of this crop produced. However, in the near future, a decrease in production as the result of climatic variations and phytosanitary factors (SIOC, 2019), such as insect pests, is expected. González-Cardona et al. (2009) demonstrated that the main plantain plantation pests in Colombia include the banana weevil (Cosmopolites sordidus Germar), the silky cane weevil (Metamasius hemipterus sericeus Linnaeus), the yellow weevil (Metamasius hebetatus Gyllenhal), the screwworm (Castniomera humboldti Maubl Ashby), the basket worm (Oiketicus kirbyi Guilding), and the kid worm (Opsiphanes tamarindi Felder). Plantain producers have generally conducted pest management using insecticides, which are toxic and pollute the environment (González-Castillo et al., 2012).
The screwworm has been identified several times as C. humboldti; however, in a study conducted by Morales and Duarte (2009), the authors found that this species had synonymy with the Telchin Hübner complex, which has three species, where $T$. atymnius is included, and is taxonomically the valid name of this species. Currently, T. atymnius is a pest with high incidence in areas cultivated with plantain, and its injuries are characterized by galleries in the corm (a short, vertical, swollen underground stem) and pseudostem (a false stem made of the rolled bases of leaves), creating entry routes for attack by other insects and pathogens and decreasing yield and fruit quality (Palencia et al., 2006).

For life cycle, Rubiano and Fernández (2010) found that the change from larvae to prepupae lasted $14 \mathrm{~d}$; prepupae to pupae lasted $11 \mathrm{~d}$; and pupae to adult 
lasted approximately $18 \mathrm{~d}$. However, crop damage is caused by larvae, which is the longest lasting stage. Adult females oviposit eggs at the base of the corm or into the pseudostem, and, when the larvae hatch, they begin to feed, forming galleries. This affects the translocation of nutrients towards the apical part of the plant, causing flag leaf death, reduced fruit quantity, and lower bunch weight (Belalcázar, 1991). The presence of larvae is typically observed as a gelatinous mass excreted at the entrance of holes, left when they enter the plant (Cedeño, 2016).

Cedeño (2016) also stated that larval instars first feed on the external socks of the plantain shoots; as they grow, they move towards the corm and through the center of the pseudostem. This habit makes its control more difficult; management of this pest must focus on capturing adult individuals. This management strategy uses traps of different colors to attract lepidopteran adults since these insects perceive color with congenital cells called "cones" in their compound eyes; they can identify a range of tones derived from the wavelengths that produce colors. For example, butterflies have three photoreceptors that absorb blue, ultraviolet, green, and yellow (Shimoda and Honda, 2013). The range of color perceived by Lepidoptera extends between 340-600 nm, demonstrating sensitivity peaks towards ultraviolet, blue, and green (Johnsen et al., 2006; Frentiu and Briscoe, 2008). In a study conducted by Joshua et al. (2007) in which white, red, and blue traps were implemented, blue traps attracted more adults of different Lepidoptera species. Other factors, such as environmental conditions, also influence the behavior of insects. Butterflies have proven to be ideal organisms for studying the effects of climate due to their poikilothermic nature, which means that their life cycles are highly influenced by climate (Stefanescu et al., 2003; Roy and Asher, 2003).

The adult screwworm is diurnal and feeds on decomposing matter, vegetable exudates, and nectar. As a result, bait, such as molasses, has been used in cylindrical traps with double effectiveness since the viscosity of molasses traps the insect, and bait with an insecticide kills the insect when it feeds, depending on the product used (Lorya et al., 2002). The composition of molasses includes sugars, such as sucrose (60-63\% by weight), glucose or dextrose (6$9 \%$ by weight), and fructose or levulose $(5-10 \%$ by weight) (Fajardo and Sarmiento, 2007). One would expect molasses to be an effective attractant for adult screwworms since most adults feed on nectar, which is composed of three main sugars: sucrose, fructose, and glucose (Goldberg, 2009). Other typical trap characteristics, such as color, shape, and texture, also influence capture effectiveness (Santos et al., 1998; Segura-León et al., 1998). The fermentation process is also a decisive factor in the daily attraction capacity during the exposure period of the traps (Liedo, 1997). Investigating new tools to complement the integrated management of the screwworm was the objective of this research through the evaluation of the efficacy of different colors and types of traps on the capture of adult screwworms on plantain farms.

\section{MATERIALS AND METHODS}

Two consecutive experiments were conducted. In Experiment $\mathrm{A}$, the color of the trap was evaluated, and subsequently, in Experiment B, two types of traps were compared.

\section{Experiment A (trap color)}

This experiment was conducted on a plantation of Dominico-Hartón plantains (Musa AAB), which was three years old and was located in the municipality of La Vega, Cundinamarca, Colombia (5'2'53.90" N and $\left.74^{\circ} 18^{\prime} 30.80^{\prime \prime} \mathrm{W}\right)$, at an altitude of $1,310 \mathrm{~m}$ a.s.l. in an area encompassing $2,000 \mathrm{~m}^{2}$.

Traps that were $1.0 \mathrm{~m}$ long and $0.6 \mathrm{~m}$ wide were elaborated with polypropylene bags with three different colors: blue, white, and transparent. Toxic bait was placed inside, composed of ripe plantain (approximately $400 \mathrm{~g}), 5 \mathrm{~g}$ of insecticide powder $\left(25 \mathrm{~g} \mathrm{~kg}^{-1}\right.$ of chlorpyrifos as the active ingredient), and $5 \mathrm{ml}$ of water. Three treatments were implemented, one for each color, and the number of captured adults was counted every $7 \mathrm{~d}$ for 7 months. The traps were renewed every $7 \mathrm{~d}$ and placed randomly every $10 \mathrm{~m}$ on the perimeter of the plot. Each trap was tied 1 $\mathrm{m}$ above the ground between two plantain plants. There were seven repetitions for each treatment.

\section{Experiment B (type of trap)}

This experiment was developed on an 8-month-old plantation of Dominico-Hartón plantains, located in the municipality of La Vega $\left(5^{\circ} 02^{\prime} 46.4^{\prime \prime} \mathrm{N}\right.$ and $\left.74^{\circ} 18^{\prime} 58.4^{\prime \prime} \mathrm{W}\right)$, at an altitude of $1,099 \mathrm{~m}$ a.s.l. and in an area of $1,000 \mathrm{~m}^{2}$. 
Based on the results obtained in Experiment A, the effectiveness of the best color trap (Color trap) was compared with the type of trap typically used by plantain producers (Artisanal trap) in the study area. The artisanal trap was elaborated with polyethylene containers (2.5 L soda bottles) with a base perimeter of $37.2 \mathrm{~cm}$ and a height of $38 \mathrm{~cm}$. An opening that was $10 \mathrm{~cm}$ wide and $5 \mathrm{~cm}$ long was made in the containers $15 \mathrm{~cm}$ from the base to allow the entry of adult screwworms, and water and molasses were added at a 2:1 ratio $(250 \mathrm{~mL}$ of water and $125 \mathrm{~mL}$ of molasses) as bait. The color trap was installed following the same methodology of Experiment A, except that it was attached to only one plant.

The captured screwworm adults were counted during the month. Trap renewal, counting periodicity, and number of repetitions were the same as in Experiment $\mathrm{A}$. In addition, an analysis of the costs associated with the two types of traps was conducted.

Furthermore, to verify the taxonomic identity of the adult screwworms ( $T$. atymnius), larvae were removed from the damaged plants and sent to the Colección Taxonómica Nacional de Insectos "Luis María Murillo" (CTNI) [National Taxonomic Collection of Insects] of the Corporación Colombiana de Investigación Agropecuaria (Agrosavia, C.I. Tibaitatá), where they were identified and deposited (catalogue number 187).

\section{Climatic variables}

In Experiment $\mathrm{A}$, the average temperature and accumulated precipitation from April to October 2017 were recorded daily; these variables were included in the corresponding model.

\section{Statistical analysis}

In both experiments, a completely randomized design was used. Since the individual adult screwworms were recorded by counting (where excess zeros were evidenced), the data were analyzed using the following models: Poisson, negative binomial (NB), zero-inflated Poisson (ZIP), and zero-inflated negative binomial (ZINB). The best model was selected by comparing Pearson's chi-square, complete log-likelihood, Akaike information criterion (AIC), corrected AIC (AICc), and Bayesian information criterion (BIC) values of each model to choose the corresponding model for Experiment A. In Experiment
B, AIC, and Schwarz Bayesian Criterion (SBC) were considered to select the best regression model. The screwworm individuals were considered the response variable; precipitation and temperature per month were the parameters in Experiment A.

For Experiment B, the parameters included trap type and capture week. The transparent color was taken as a benchmark in Experiment A to evaluate the effectiveness of the other colors because blue and white represented positive parameters in the regression model in contrast to the transparent color, which always demonstrated negative parameters (when it was not used as a reference point). In Experiment B, the color trap was taken as a reference point for the model because it represented a negative parameter. The parameters were considered significant when $P<0.05$. For the statistical analysis, Statistical Analysis System (SAS) 9.4 was used.

\section{RESULTS AND DISCUSSION}

The screwworm life cycle stages (T. atymnius) are shown in figure 1 . They were collected and deposited in CTNI.

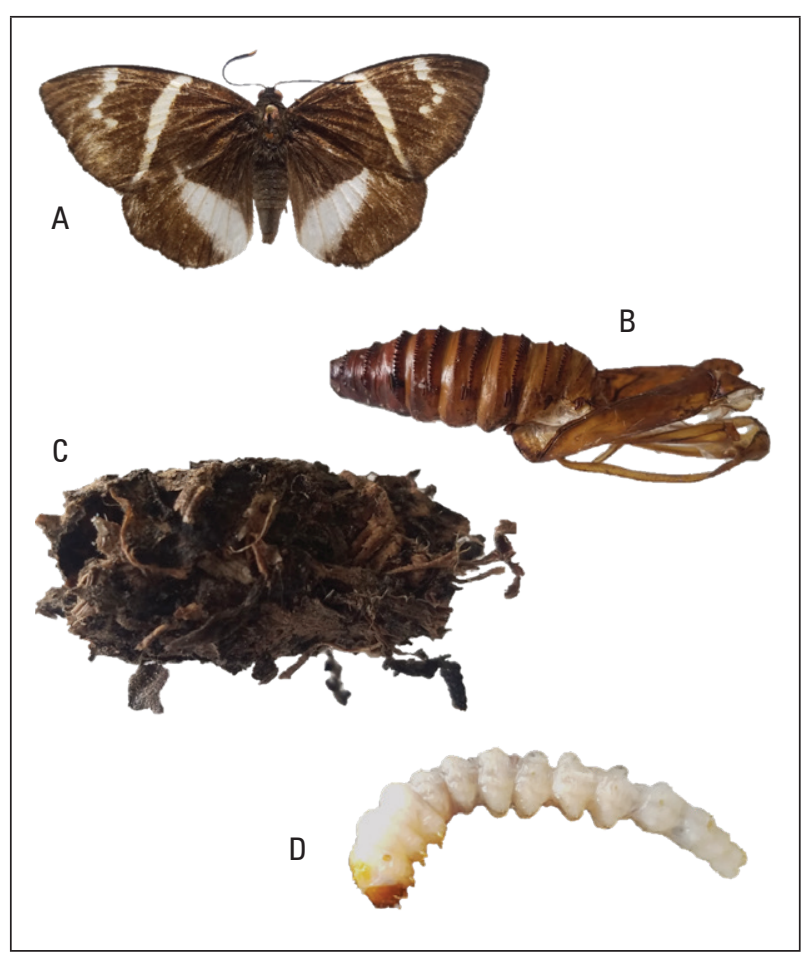

Figure 1. Screwworm (T. atymnius). A. Adult; B. Pupal exuviae; C. Pupal house, and D. Larva. 
In both experiments, the adults collected in the traps were dead or had damage to their wings that did not allow them to fly.

\section{Experiment A (trap color)}

The best fitting regression model was selected by comparing Pearson's chi-square (closer to 1) and the lower values in the complete log-likelihood criterion, AIC, AICc, and BIC (Tab. 1).

This allowed selection of the best model, namely, the ZINB model, which presented the best selection criteria values. It is important to note that the ZIP model was not selected because the negative of the Hessian was not a positive definite.

Based on the parameters estimated by the selected model, the blue and white color traps captured 2.84 $\left(e^{1.0443}=2.84\right)$ and $1.38\left(e^{0.3220}=1.38\right)$ more adult screwworms, respectively, than the transparent trap (Tab. 2), a finding that coincides with Pérez (2013). Likewise, in studies conducted by Goulson and Cary (1993) and Weiss (1997) with blue, red, yellow, and white traps, they observed that blue traps captured up to eight different species of Lepidoptera. Furthermore, Kočíková et al. (2012) used traps of different colors to determine the effect of color on the behavior of butterflies (Lepidoptera: Hesperioidea and Papilionoidea). They discovered that white traps had higher captures followed by blue and violet ones. This finding could be related to peaks in the blue spectrum and the presence of UV and blue receptors in butterflies. Taha et al. (2012) found that blue sticky traps captured significantly more Lepidoptera adults, namely, T. absoluta (22.98\%), than yellow sticky traps (13.99\% of total adults), whereas there was no difference between the numbers captured by blue and green traps. The results of this study demonstrated that $T$. atymnius preferred blue to white, contrary to that reported for other Lepidoptera species, such as T. absoluta, which appeared to prefer white over blue (Tadele and Emana, 2017).

Tadele and Emana (2017) discovered that, in greenhouse tomatoes, T. absoluta had a different attraction to several colors in the following decreasing order: white $>$ blue $>$ yellow $>$ green $>$ red. The maximum number of adults was captured with white sticky traps, followed by blue ones. The minimum number of adults was captured with red and green sticky traps. Furthermore, Mahmoud et al. (2014) found that $T$. absoluta adults exhibited a higher preference for white traps.

Table 1. Selection criteria for the four regression models used in Experiment A.

\begin{tabular}{|l|c|c|c|c|}
\hline \multicolumn{1}{|c|}{ Criterion } & ZIP & ZINB & NB & Poisson \\
\hline Pearson's Chi-squared test & 1.2516 & 1.2502 & 1.3071 & 1.3139 \\
\hline Complete Log-Likelihood & -160.7383 & -160.7409 & -161.3024 & -161.3053 \\
\hline AIC & 337.4766 & 339.4817 & 334.6048 & 332.6107 \\
\hline AICC & 338.3822 & 340.6210 & 335.1266 & 332.9810 \\
\hline BIC & 362.4683 & 367.5974 & 353.3486 & 348.2305 \\
\hline
\end{tabular}

ZIP (Zero-Inflated Poisson), ZINB (Zero-Inflated Negative Binomial), NB (Negative Binomial), AIC (Akaike's Information Criterion), AICc (corrected Akaike's Information Criterion), and BIC (Bayesian Information Criterion).

Table 2. Parameters of the Zero-Inflated Negative Binomial model (including climatic variables) for data on captures of adult screwworm individuals using different color traps.

\begin{tabular}{|l|c|c|c|c|c|c|}
\hline \multicolumn{1}{|c|}{ Parameter } & Estimate & Standard error & \multicolumn{2}{c|}{ Confidence limits of Wald to 95\% } & Chi-square of Wald & Pr $>$ Chi-Sq. \\
\hline (Intercept) & -41.6656 & 6.9747 & -55.3358 & -27.9953 & 35.69 & $<.0001$ \\
\hline Blue color & 1.0443 & 0.5332 & -0.0009 & 2.0894 & 3.84 & 0.0502 \\
\hline White color & 0.3220 & 0.5465 & -0.7492 & 1.3932 & 0.35 & 0.5558 \\
\hline Transparent & 0.0000 & 0.0000 & 0.0000 & 0.0000 & - & - \\
\hline Temperature & 1.8339 & 0.3190 & 1.2088 & 2.4591 & 33.06 & $<.0001$ \\
\hline Precipitation & 0.0056 & 0.0015 & 0.0026 & 0.0086 & 13.45 & 0.0002 \\
\hline
\end{tabular}


On the other hand, when the temperature increased, the adult insect captures increased by 6.26 times $\left(e^{1.8339}=6.26\right.$, Tab. 2$)$, as compared to the month with the lowest temperature. Likewise, when rainfall increased, the adult insect captures increased by 1.01 times $\left(e^{0.0056}=1.01\right.$, Tab. 2$)$.

Figure 2 shows that rain increased just before the experiment was initiated. Therefore, it would be expected that favorable conditions for insect development occurred in the period prior to trap setting. These results, together with the absence of control methods, led to higher captures at the beginning of the experiment. According to Belalcázar (1991), screwworms are diurnal, are more active on sunny days, and fly in small groups $1 \mathrm{~m}$ above the ground. In June and July, there was a decrease in screwworm captures in response to trap installations in April and May, which reduced the insect population. Later, in August, there was an increase in screwworm captures that could be explained by high adult populations appearing in April and May whose offspring likely turned into adults by August.

With low rainfall and temperature increases in June and July, it would be expected that the reproduction and activity of these insects would be favored (Londoño et al., 1991), so the insect population in September and October would increase. However, the adult numbers during the low rainfall period was the lowest; the initial population might not have been enough to achieve a significant increase in the subsequent months. In addition, the trap installations decreased the chances for the reproduction and development of insects. In this regard, Arboleda and
Parra (2012) found that the population indices of $C$. humboldti (Lepidoptera: Castniidae), considering the number of larvae and eggs per plant during a plantain plague in Buenaventura (Colombia), demonstrated a positive and significant relationship with precipitation; however, it demonstrated no significant relationship with relative humidity or with temperature.

According to Urra (2016), rainfall could have either favorable or unfavorable effects on insects, depending on the type of insect, its development stage, and habits. The development rate of immature stages (egg, larva and pupa) fluctuates according to environmental temperatures within a range of $10-30^{\circ} \mathrm{C}$ although, for many species, a higher temperature is favorable, and warmer periods lead to premature larval development and, consequently, the rapid development of adult insects (Stefanescu et al., 2004). In the current study, a temperature range of $21.3-22.1^{\circ} \mathrm{C}$ prevailed in the area where the experiments were performed.

Raupp (2006) claimed that rain not only represented a direct threat of injury or death to butterflies but the fresh air associated with storms could also reduce temperatures below the thermal threshold for insect flight. Furthermore, cloudy skies limit the ability to collect the solar radiation necessary to fly (Roy and Asher, 2003; Raupp, 2006).

\section{Experiment B (type of trap)}

By comparing the lowest values with AIC and SBC (Tab. 3), the best-fit regression model was selected, namely, the Poisson model, which demonstrated the best values for the selection criteria.

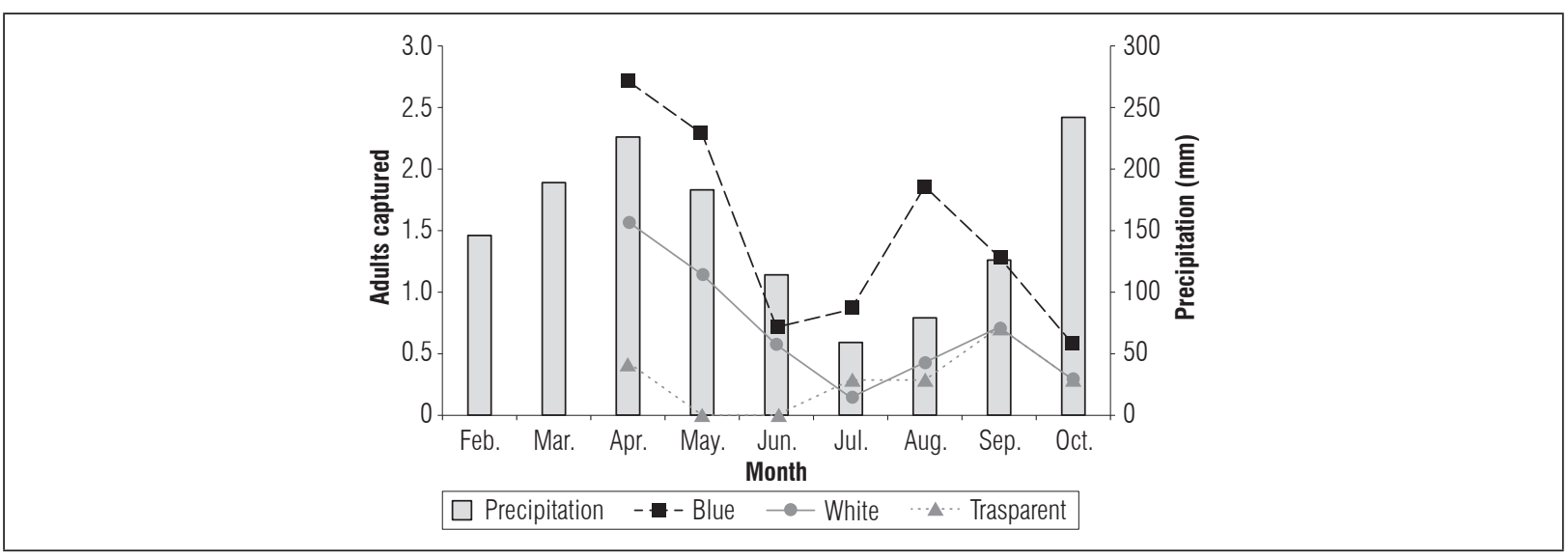

Figure 2. Variation of screwworm individual captures using different color traps and rainfall changes in the study area from April to October 2017. Adult capture is represented as the average weekly count for each month. 
Table 3. Selection criteria of the four regression models used in Experiment B.

\begin{tabular}{|c|c|c|c|c|}
\hline Criterion & ZIP & ZINB & NB & Poisson \\
\hline AIC & 114.10879 & 114.10878 & 113.59718 & 111.59718 \\
\hline SBC & 122.74432 & 122.74432 & 120.07383 & 115.91495 \\
\hline
\end{tabular}

ZIP (Zero-Inflated Poisson), ZINB (Zero-Inflated Negative Binomial), NB (Negative Binomial), AIC (Negative Binomial), and SBC (Schwarz Bayesian Criterion).

Table 4. Parameters of the Poisson model for capturing screwworm individuals with the use of two traps.

\begin{tabular}{|l|c|c|c|c|}
\hline \multicolumn{1}{|c|}{ Parameter } & Estimate & Standard error & t-value & Pr $>|\mathbf{t}|$ \\
\hline Intercept & -1.673976 & 0.408248 & -4.10 & $<.0001$ \\
\hline Artisanal trap & 1.466337 & 0.452911 & 3.24 & 0.0012 \\
\hline Color trap (blue) & 0 & - & - & - \\
\hline
\end{tabular}

The comparison of the two trap types with Poisson modeling indicated that the most efficient trap for capturing screwworm adults was the artisanal trap, over the blue trap (Tab. 4). Based on the parameters estimated by the model, the artisanal traps captured 4.33 times $\left(e^{1.466337}=4.33\right)$ more individual adult screwworms than the blue traps. Lorya et al. (2002), considering the establishment of adult emergence periods and the population dynamics of Opsiphanes cassina Felder (Lepidoptera: Brassolidae), found the most effective traps for capturing adults of this species were those containing molasses bait.

It is important to note that, in this experiment, the plantain crops were in their vegetative growth stage, in contrast to the first experiment, where the plants were in their third productive cycle. Tadele and Emana (2017) stated that the effectiveness of a trap depends on when it was set in relation to the phenology of the crop. These authors discovered that the highest number of $T$. absoluta individuals captured in all tomato development stages (vegetative, flowering, and fruiting) was obtained with the white sticky trap, followed by the blue one.

The attractive odor of molasses is a more effective tool for monitoring and controlling insect populations from the integrated pest management perspective because adults are strongly attracted to carbohydrate and protein sources (Chinchilla, 2003; Rodríguez et al., 2009). This phenomenon could explain why the artisanal trap was able to capture a greater number of screwworms. A traditional bait widely used successfully in trap studies in the neotropics is a mixture of ripe banana with sugarcane juice or molasses diluted in water; when fermented, it attracts butterflies that feed on fruits (Freitas et al., 2014).

Table 5 shows the materials and the cost per unit (in USD cents) for manufacturing each trap type used in Experiment B. The cost of manufacturing the artisanal trap was $12 \%$ less than manufacturing the blue trap, making it more affordable for producers.

Table 5. Total manufacturing price in USD of each tarp type.

\begin{tabular}{|c|c|c|c|}
\hline Type of trap & Materials & Quantity/Trap & Cost $(c)$ \\
\hline \multirow{6}{*}{$\begin{array}{l}\text { Color trap } \\
\text { (blue) }\end{array}$} & Blue bag & 1 unit & 32 \\
\hline & Ripe plantain & 1 unit & 23 \\
\hline & Chlorpyrifos & $5 \mathrm{~g}$ & 0.3 \\
\hline & Wire & $1 \mathrm{~m}$ & 26 \\
\hline & Fiber & $1 \mathrm{~m}$ & 2 \\
\hline & \multicolumn{2}{|c|}{ Total } & 83 \\
\hline \multirow{4}{*}{ Artisanal trap } & Plastic bottle & 1 unit & 7 \\
\hline & Molasses & $1 \mathrm{~kg}$ & 65 \\
\hline & Fiber & $1 \mathrm{~m}$ & 2 \\
\hline & \multicolumn{2}{|c|}{ Total } & 73 \\
\hline
\end{tabular}

Exchange rate: 1 USD is equivalent to COP 3,098.33.

The artisanal trap displayed greater technical efficiency in catching $T$. atymnius adults, facilitating their implementation by plantain producers in the area. Additionally, this trap does not use agrochemicals, and the plastic bottle can be reused. 


\section{CONCLUSION}

The results of this research confirm the relationship between trap color and efficiency. The blue color traps were the most efficient in capturing adult screwworms (T. atymnius). However, by contrasting the technical effectiveness and financial viability of the blue trap using toxic bait with traps that were made with plastic bottles and water-molasses bait (artisanal traps made by plantain producers), it was found that the latter was more effective than the blue bag traps with toxic bait. Based on this analysis, the artisanal traps represent an economic and sustainable alternative for monitoring and capturing adult screwworms. These traps attract adults and prevent oviposition, thereby reducing the need for insecticide applications with direct plant spraying, which is inefficient because of the larva's habit of remaining inside the pseudostem of the banana plant. In this research, the increase in the capture of $T$. atymnius was associated with increases in accumulated monthly precipitation values and average temperatures.

Conflict of interests: The manuscript was prepared and reviewed with the participation of the authors, who declare that there exists no conflict of interest that puts at risk the validity of the presented results.

\section{BIBLIOGRAPHIC REFERENCES}

Arboleda, N. and C. Parra. 2012. Principales aspectos bioetológicos de Castniomera humboldti (Lepidoptera: Castniidae) como plaga del cultivo de plátano en áreas de la comunidad de Zabaletas, zona rural del Distrito de Buenaventura. Bioetnia 9(1), 65-72.

Belalcázar, S. 1991. El cultivo de plátano en el trópico. Instituto Colombiano Agropecuario, Armenia, Colombia. pp. 311-312.

Cedeño, D. 2016. Efecto de tres biofertilizantes sobre el desarrollo del banano (Musa paradisiaca L.). Undergraduate thesis. Facultad de Ciencias Agrarias, Universidad de Guayaquil, Ecuador.

Chinchilla, C. 2003. Manejo integrado de problemas fitosanitarios en palma aceitera Elaeis guineensis en América Central. Manejo Integr. Plagas Agroecol. 67, 69-82.

Fajardo, E. and S. Sarmiento. 2007. Evaluación de melaza de caña como sustrato para la producción de Saccharomyces cerevisiae. Undergraduate thesis. Facultad de Ciencias, Universidad Pontificia Universidad Javeriana, Bogota.

Freitas, A.V.L., C.A. Iserhard, J.P. Santos, J.Y.O. Carreira, D.B. Ribeiro, D.H.A. Melo, A.H.B. Rosa, O.J.M. Filho, G.M. Accacio, and M.U. Prado. 2014. Studies with butterfly bait traps: an overview. Rev. Colomb. Entomol. 40(2), 209-218.

Frentiu, F.D. and A.D. Briscoe. 2008. A butterfly eye's view of birds. BioEssays 30, 1151-1162. Doi: 10.1002/ bies.20828

Goldberg, L. 2009. Patterns of nectar production and composition, and morphology of floral nectaries in Helicteres guazumifolia and Helicteres baruensis (Sterculiaceae): two sympatric species from the Costa Rican tropical dry forest. Rev. Biol. Trop. 57(Suppl. 1), 161-177.

González-Cardona, C., J.C. Aristizábal-Hincapié, and M. Aristizábal-Loaiza. 2009. Evaluación biológica del manejo de picudos y nematodos fitopatógenos en plátano (Musa AAB). Acta Agron. 58(4), 260-269.

González-Castillo, M., C.N. Aguilar, and R. Rodríguez-Herrera. 2012. Control de insectos-plaga en la agricultura utilizando hongos entomopatógenos: retos y perspectivas. Rev. Cient. Univ. Auton. Coahuila 4(8), 42-55.

Goulson, D. and J.S. Cory. 1993. Flower constancy and learning in foraging preferences of the green-veined white butterfly Pieris napi. Ecol. Entomol. 18, 315-320. Doi: 10.1111/j.1365-2311.1993.tb01107.x

Johnsen, S., A. Kelber, E. Warrant, A.M. Sweeney, E.A. Widder, R.L. Lee, and J. Hernández-Andrés. 2006. Crepuscular and nocturnal illumination and its effects on color perception by the nocturnal hawkmoth Deilephila elpenor. J. Exp. Biol. 209, 789-800. Doi: 10.1242/ jeb.02053

Joshua, W., J. Campobell, and L. Hanbula. 2007. Efficiency of malaise traps and colors pan traps for collecting flower visiting insects from three forested ecosystems. J. Insect Conserv. 11(1), 399-408. Doi: 10.1007/ s10841-006-9055-4

Kočíková, L., D. Miklisová, A. Čanády, and L'. Panigaj. 2012. Is colour an important factor influencing the behaviour of butterflies (Lepidoptera: Hesperioidea, Papilionoidea)? Eur. J. Entomol. 109(3), 403-410. Doi: 10.14411/eje.2012.052

Liedo, P.F. 1997. Bases teóricas y conceptos sobre trampeo y atrayentes. pp. 121-128. In: Curso regional sobre moscas de la fruta y su control en áreas grandes con énfasis en la técnica del insecto estéril. Centro Internacional de Capacitación en Moscas de la Fruta. Chiapas, México.

Londoño, M.E., J. Pulido, F. García, I. De Polania, and G. Leon. 1991. Manejo integrado de plagas. pp. 301-326. In: Belalcazar, S. (ed.). EI cultivo del plátano en el trópico. Instituto Colombiano Agropecuario, Armenia, Colombia.

Lorya, R., C. Chinchilla, J. Domínguez, and R. Mexzón. 2002. Una trampa efectiva para capturar adultos de Opsiphanes cassina Felder (Lepidoptera: Brassolidae) y observaciones sobre el comportamiento de la plaga en palma de aceite. Palmas 23(1), 29-37. 
Mahmoud, Y.A., I.M.A. Ebadah, A.S. Abd-Elrazik, T.E. Abd-Elwahab, and S.H. Deif. 2014. Efficiency of different colored traps baited with pheromone in capturing tomato adult moth, Tuta absoluta (Meyrick) (Lepidoptera: Gelechiidae) during summer plantation. World Appl. Sci. J. 30(4), 406-412.

Morales, S. and M. Duarte. 2009. Morfología externa comparada das três espécies do complexo Telchin licus. Rev. Bras. Entomol. 53(2), 245-265. Doi: 10.1590/ S0085-56262009000200007

Palencia, G., R. Gómez, and J. Martin. 2006. Manejo sostenible del cultivo del plátano. Corpoica, Bucaramanga, Colombia.

Pérez, E. 2013. Influencia del color de trampa sobre la captura de machos de Copitarsia decolora (Guenée) en coliflor. Undergraduate thesis. Facultad de Agronomía y Veterinaria, Universidad Autónoma de San Luis Potosí, San Luis Potosí, Mexico.

Raupp, M. 2006. What do butterflies do when it rains? In: Scientific American, https://www.scientificamerican. com/article/what-do-butterflies-do-wh/; consulted: January, 2019.

Rodríguez, G., R. Silva, R. Barrios, A. Díaz, R. Casares, E. González, and E. Milano. 2009. Evaluación de atrayentes orgánicos para la captura de adultos de Opsiphanes cassina Felder, defoliador de la palma aceitera. Agron. Trop. 59(2), 173-182.

Roy, D.B. and J. Asher. 2003. Spatial trends in the sighting dates of British butterflies. Int. J. Biometeorol. 47, 188-192. Doi: 10.1007/s00484-003-0170-6

Rubiano, J.A. and N.P. Fernández. 2010. Gusano tornillo (Castniomera humboldti), plaga de importancia económica en el cultivo del plátano en Buenaventura, Valle del Cauca, Colombia. Investig. Biodivers. Desarro. 29(2), 150-154.

Santos, E., V. Cid Prado, and J.T. Cibrián. 1998. Evaluación de tratamientos para la captura de adultos del mayate prieto Rhynchophorus palmarum L. en la Costa Grande, Guerrero. pp. 567-569. In: Mem. 33 Congreso Nacional de la Sociedad Mexicana de Entomología. Acapulco, Mexico.
Segura-León, O.L., C.F. Ortiz-García, and J. Cibrián-Tovar. 1998. Manejo del picudo del cocotero Rhynchophorus palmarum L. con atrayentes en Tabasco. pp. 576-582. In: Mem. 33 Congreso Nacional de la Sociedad Mexicana de Entomología. Acapulco, Mexico.

Shimoda, M. and K. Honda. 2013. Insect reactions to light and its applications to pest management. Appl. Entomol. Zool. 48(1), 413-421. Doi: 10.1007/ s13355-013-0219-x

SIOC, Sistema de Información de Gestión y Desempeño de Organizaciones de Cadenas. 2019. Plátano. In: https://sioc.minagricultura.gov.co/Platano/Pages/default.aspx; consulted: January, 2019.

Stefanescu, C., S. Herrando, and F. Páramo. 2004. Butterfly species richness in the northwest Mediterranean Basin: the role of natural and human-induced factors. J. Biogeogr. 31, 905-915. Doi: 10.1111/j.1365-2699.2004.01088.x

Stefanescu, C., J. Peñuelas, and I. Filella. 2003. Effects of climate change on the phenology of butterflies in the northwest Mediterranean Basin. Global Change Biol. 9, 1494-1506. Doi: 10.1046/j.1365-2486.2003.00682.x

Tadele, S. and G. Emana. 2017. Evaluation of colored sticky traps for the monitoring of Tuta absoluta Meyrick (Lepidoptera: Gelechiidae) in tomato under glasshouse in Ethiopia. Agri. Res. Tech. 9(3), 555762. Doi: 10.19080/ ARTOAJ.2017.09.555762

Taha, A.M., B.H. Homam, A.F. Afsah, and M. El-Sharkawy-Fatma. 2012. Effect of trap color on captures of Tuta absoluta moths (Lepidoptera: Gelechiidae). Int. J. Emerg. Sci. Eng. 3, 43- 48.

Urra, F. 2016. Cuando llueve, los insectos no sólo se mojan. In: Nota Área de Entomología of the Servicio Nacional de Patrimonio Cultural, http://www.mnhn.gob. cl/613/w3-article-56028.html? noredirect $=1$; consulted: January, 2019.

Weiss, M.R. 1997. Innate colour preferences and flexible colour learning in the pipevine swallowtail. Animal Behav. 53, 1043-1052. Doi: 10.1006/anbe.1996.0357 